
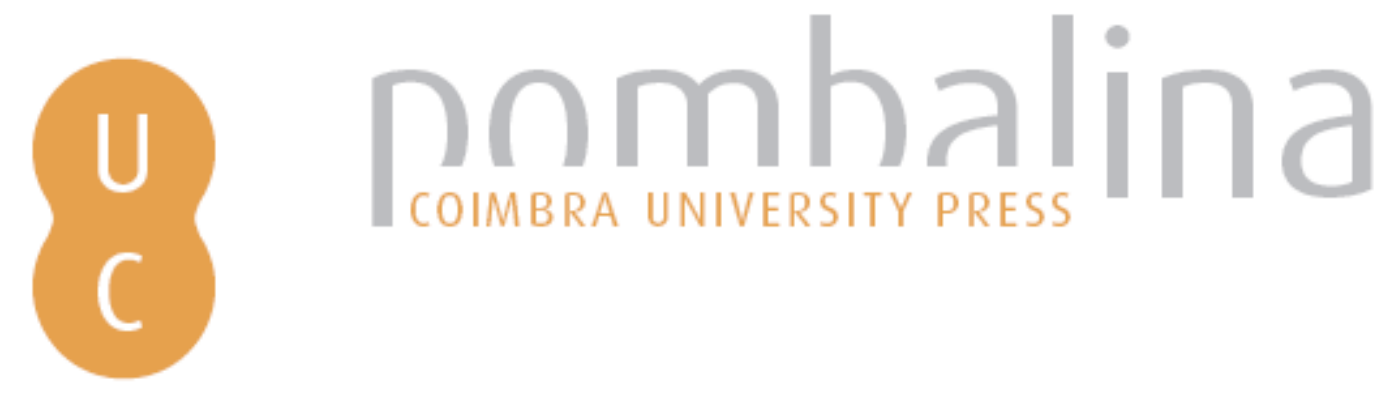

\title{
Revolução e revisionismo historiográfico: o 25 de Abril visto da história
}

Autor(es): $\quad$ Cruzeiro, Maria Manuela

Publicado por: Imprensa da Universidade de Coimbra

URL

persistente:

URI:http://hdl.handle.net/10316.2/31333

DOI:

DOI:http://dx.doi.org/10.14195/978-989-26-0465-7_3

Accessed : $\quad$ 26-Apr-2023 15:27:49

A navegação consulta e descarregamento dos títulos inseridos nas Bibliotecas Digitais UC Digitalis, UC Pombalina e UC Impactum, pressupõem a aceitação plena e sem reservas dos Termos e Condições de Uso destas Bibliotecas Digitais, disponíveis em https://digitalis.uc.pt/pt-pt/termos.

Conforme exposto nos referidos Termos e Condições de Uso, o descarregamento de títulos de acesso restrito requer uma licença válida de autorização devendo o utilizador aceder ao(s) documento(s) a partir de um endereço de IP da instituição detentora da supramencionada licença.

Ao utilizador é apenas permitido o descarregamento para uso pessoal, pelo que o emprego do(s) título(s) descarregado(s) para outro fim, designadamente comercial, carece de autorização do respetivo autor ou editor da obra.

Na medida em que todas as obras da UC Digitalis se encontram protegidas pelo Código do Direito de Autor e Direitos Conexos e demais legislação aplicável, toda a cópia, parcial ou total, deste documento, nos casos em que é legalmente admitida, deverá conter ou fazer-se acompanhar por este aviso.

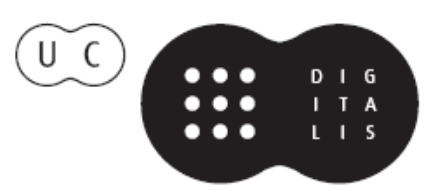




\section{R U I \\ C U N H A \\ M A R T I N S}

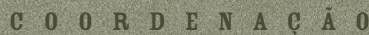

\section{PORTUGAL}
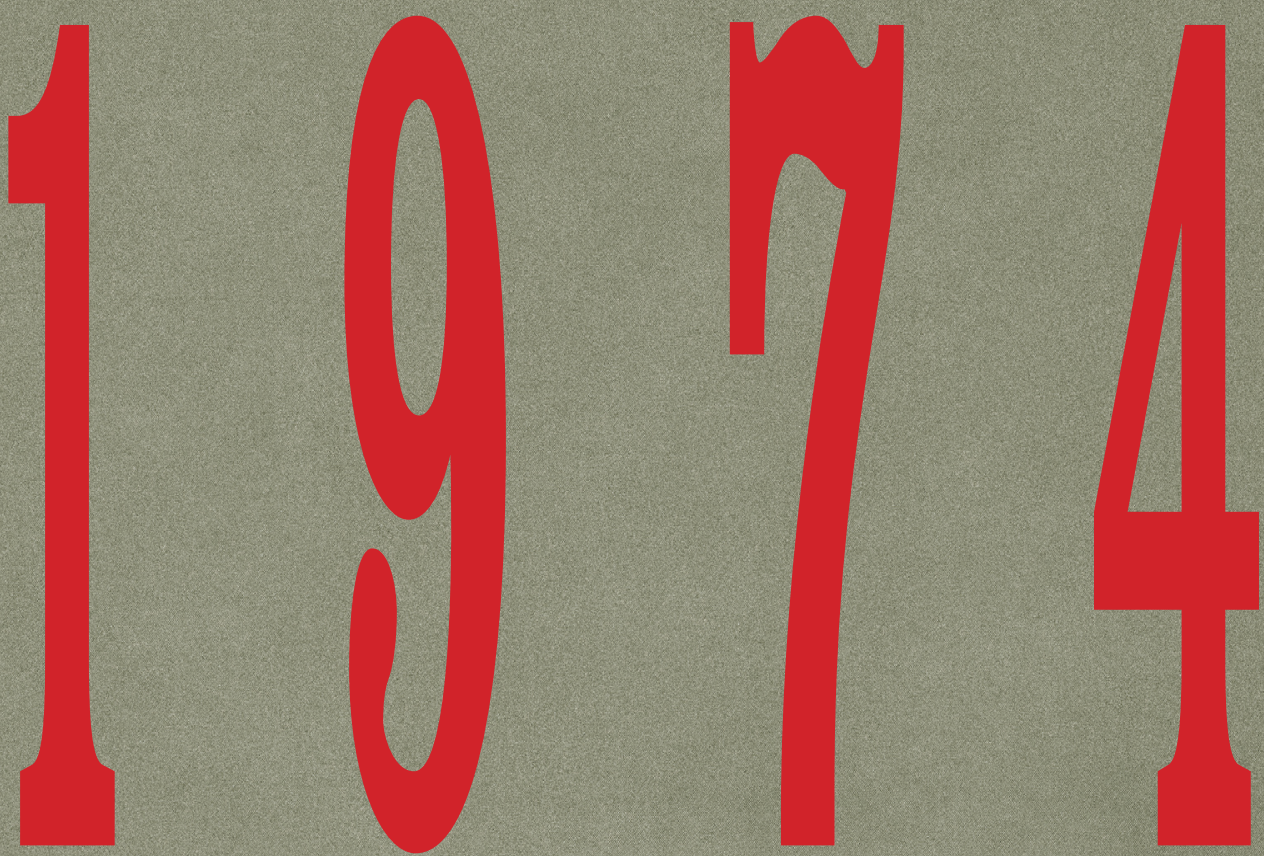

Transiçấo

PoLitica EM

Perspectiva

HISTÓRICA

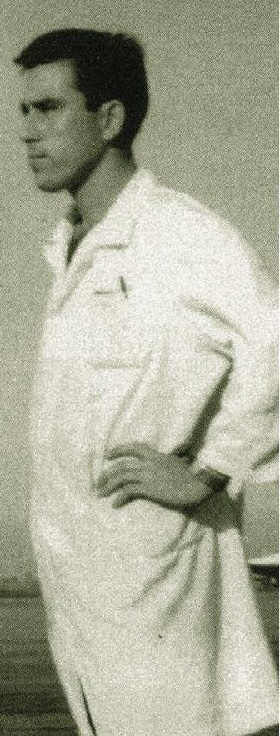




\section{REVOluÇão e REVisionismo Historiográfico. O 25 DE ABRIL Visto dA História}

MARIA MANUELA CRUZEIRO ${ }^{146}$

1.

O fenómeno revolucionário constitui matéria complexa e apaixonante que, compreensivelmente, se impõe como objecto de uma vastíssima bibliografia proveniente de áreas tão diferentes como a história, a sociologia, a ciência política, a economia, os estudos culturais. Na variedade e relativa autonomia de análise de cada uma dessas áreas, um essencial objectivo comum as une: o esforço de desvendar o fio que liga uma transformação radical do poder às mudanças da estrutura social e política, dos modelos culturais, éticos ou religiosos que precedem ou acompanham tal transformação.

Tarefa complexa que começa logo que se tenta delimitar o significado do vocábulo 'Revolução', uma vez que o levantamento da sua evolução semântica revela uma ampla polissemia não só no campo da história, mas no de outras áreas do saber, com as quais, à partida, pareceria não ter qualquer afinidade. E é justamente numa área bem específica, a da astrologia, que o conceito nasce com um significado não só distinto, mas até oposto ao que lhe atribuímos hoje. Na verdade, a célebre obra de Copérnico De Revolutionibus orbium caelestium libri (1543) estudava os movimentos circulares dos corpos celestes e a 'revolução' por eles cumprida era, no seu sentido literal, percurso circular, retorno, mudança de direcção, regresso ao ponto de partida.

${ }^{146}$ Centro de Estudos Sociais da Universidade de Coimbra 
E foi este o sentido que, agora aplicado ao mundo da política, Hauréau lhe fixou no seu Dictionnaire Politique (1842). Tratava-se afinal de recuperar um sentido total e radicalmente alterado em 1789 com a Revolução Francesa e o fazer regressar à velha doutrina de Aristóteles, Políbio, Maquiavel e tantos outros, sobre o ciclo das constituições, ou seja, sobre a forma de governo dos homens. Havia, assim, um número limitado de formas constitucionais que se sucediam numa sequência ditada pelo seu próprio processo degenerativo mas que, por natureza, não podiam ser superadas.

Cada mudança conduzia a um regime já conhecido, dado que os homens eram obrigados a viver segundo ciclos fisiopolíticos impossíveis de alterar. A experiência histórica estava, assim, ligada a pressupostos naturais que se sucediam com uma regularidade semelhante às próprias leis da natureza.

Portanto, até ao século XviII a revolução política era sinónimo de repetição e não contemplava outros acontecimentos como agitações e revoltas sociais de toda a ordem, fenómenos que eram remetidos para o campo da violência e reprimidos enquanto tais. Nesse domínio cabia um vasto leque de expressões que, remontando à Idade Média, se prolongaram até ao sec. XVI e XVII, como revolta, insurreição, agitação, rebelião, sedição, guerra intestina, guerra civil, mas nunca revolução que, curiosamente, se mantinha confinada ao domínio das mudanças de governo pacíficas e lentas, mas sempre com a forte componente de regresso ou de retorno cíclico ao estádio inicial. Como escreve Reinhart Koselleck 'Non si disponeva di nessuna parola che indicasse un rivolgimento in cui gli stessi sudditi divenissero sovrani (Hannah Arendt). L'emancipazione sociale come processo rivoluzionario era ancora al di là dell' esperienza.'147 Tudo mudou com o Iluminismo e o seu optimismo histórico e antropológico, a sua crença no progresso civilizacional e na ilimitada capacidade do homem para se libertar de todo o tipo de obscurantismo, servidão e violência. A revolução deixa então de se aplicar a uma mera mudança política para se expandir a todos os domínios da história autenticamente humana: do direito à religião, passando pelos costumes, a economia, a organização do estado. Mas,

\footnotetext{
${ }^{147}$ Reinhart Koselleck, Futuro Passato, Per una semântica dei tempi storici, Bolonha, CLUEB, 2007 , p. 61.
} 
apesar dessa amplitude de sentido, em que confluíam todas as esperanças utópicas, o conceito mantinha, particularmente na sua dimensão estritamente política, uma característica essencial: a negação de toda a violência. Nesse sentido se assume como contraponto e superação conceptual da subversão mais rude e cruel: a guerra civil. Fascinados pela Revolução Inglesa de 1688, a qual substitui uma dinastia tirânica e impopular por um regime parlamentar, iluministas como Voltaire admiram acima de tudo o prodígio de tal experiência ter sido levada a cabo com êxito sem qualquer derramamento de sangue. 'Cosi, Voltaire constatava con ammirazione come in Inghilterra avesse avuto luogo una rivoluzione, mentre in altri paesi non si era andati al di là di rivolte e di guerre civili cruente e senza risultati. La guerra civili assunse, cosi, per più rispetti, il significato di un assurdo girare a vuoto, rispetto al qual la rivoluzione poteva aprire un nuovo orizzonte.' ${ }^{148}$

É, pois, com a Revolução Francesa que o vocábulo adquire um significado muito próximo do actual, com as oscilações inevitáveis dos diferentes contextos sócio-políticos ou geográficos. Pode, assim, dizer-se que o vocábulo 'revolução', tal como o entendemos, é um produto linguístico dos tempos modernos, nascido em solo francês. Só a partir de 1789 ela deixa de ser essa espécie de movimento circular de regresso a situações já vividas no passado, para abrir para um futuro totalmente desconhecido que desafia constantemente a reflexão e a acção política. Um novo conceito que, dada a sua complexidade, se vai construindo por etapas e sobretudo por um diálogo nem sempre fácil nem linear entre a revolução pensada e os sucessos e insucessos das suas tentativas de concretização. Novo, antes de mais, porque se trata de um conceito meta-histórico, um princípio regulador do conhecimento e da praxis humana, na medida em que se desloca da sua origem natural, e tende a dar um enquadramento histórico e um sentido prospectivo às experiências subversivas, que passam assim a ser olhadas como etapas positivas de progresso para a humanidade e não como episódios de destruição e violência gratuitos.

${ }^{148}$ Ibidem, p. 62 
Novo conceito também, na medida em que essa libertação do modelo natural configura uma profunda alteração na percepção do tempo histórico, o qual, se até aqui tinha ritmos pré-determinados, pode agora ser acelerado e precipitar novas formas de organização políticas e sociais, sem qualquer paralelismo com aquelas já conhecidas do passado.

Novo conceito finalmente, porque a revolução deixa de ser apenas política, para se alargar ao todo social. Ou mais precisamente: o objectivo de toda a revolução política é a transformação de toda a estrutura social. O desígnio de que a revolução devia cumprir um vasto programa de aspirações sociais paradigmaticamente consagradas na célebre trilogia da Revolução Francesa (e exportada para outros tantos contextos) "Liberdade, Igualdade e Fraternidade", prova essa indissolúvel aliança entre político e social. Este ambicioso programa utópico e libertador, que se mantém como intocável mas inalcançável património universal da mãe de todas as revoluções, alimentou um vastíssimo campo de reflexão com destaque para o marxismo que, compreensivelmente, dedica à teoria da revolução uma importância nuclear. Na verdade, a afirmação de Marx de que 'toda a revolução dissolve a velha sociedade e neste sentido é social; toda a revolução dissolve o velho poder, e neste sentido é politica', traduz o ideal revolucionário tal como foi sendo delineado por Engels, Marx e Lenine, respectivamente em $A$ Origem da Família, da Propriedade Privada e do Estado, O 18 Brumário de Louis Bonaparte e O Estado e a Revolução.

Não estando nos nossos objectivos a análise de cada um destes textos, tão diversos não só no conteúdo como na metodologia, em todas as suas implicações (como por exemplo a teoria do Estado ou da luta de classes) interessa-nos sobretudo sublinhar o que neles é nuclear para a clarificação dessa nova ideia de revolução radical simultaneamente política e social. A começar pelo aspecto mais conhecido e também mais controverso de todos: o carácter estruturalmente violento do fenómeno revolucionário. Como escreveu Lenine, 'una revolución es, indudablemente, la cosa más autoritaria que existe; es el acto mediante el cual una parte de la población impone su voluntad a la otra parte por medio de fusiles, bayonetas y cañones, medios autoritarios si los hay; y el partido victorioso, si non quiere haber luchado en vano, tiene que mantener este dominio por el terror 
que sus armas inspiran a los reaccionários. ${ }^{149}$ Essa violência, 'parteira da história' para Engels, e a sua expressão máxima, o 'terror', é, pois, encarada por Lenine, como o fora para os revolucionários franceses, ${ }^{150}$ não como um mal necessário ou sequer explosão incontrolável de tendências destrutivas do corpo social, mas sim como um conceito correlativo desse outro que é a base da sua teoria social: a luta de classes. Como verdadeiro motor da história, esse conflito permanente surge à luz do dia em períodos de crise e é escondido (mas não anulado) em períodos normais, remetido para o poder de Estado, aparentemente neutro e imparcial. Mas o seu carácter irreconciliável, o domínio de uma classe por outra, permanece nesse poder de Estado, que mais não é do que um instrumento dessa mesma opressão. Ora é este poder opressivo do Estado Burguês que não pode ser simplesmente substituído pelo Estado Proletário, mas sim destruído por uma revolução violenta. Ao contrário, o Estado Proletário é que só será suprimido por um processo de extinção.

Esta ideia da necessidade da substituição violenta do Estado Burguês pelo Estado Proletário apresenta-se ao marxismo como inquestionável ensinamento extraído da observação concreta e rigorosa da experiência de cada revolução passada, e não apenas do modelo teórico da concepção materialista da história. E nesse aspecto o 18 Brumário, enquanto balanço da experiência francesa de 1848 a 1851 (período em que, segundo Marx, a França viveu de uma forma rápida e concentrada os processos de desenvolvimento próprios de todo o mundo capitalista) revela-nos um Marx historiador que sob a pressão dos acontecimentos parece privilegiar o seu relato, a descrição exaustiva das suas múltiplas variáveis estritamente políticas, à ortodoxia teórica da sua explicação segundo o modelo tradicional da relação infra-superestrutura e da determinação do político pelo econó-

149 V.I. Lenine, El Estado y la Revolucion, in V.L. Lenine, Obras Escogidas em Três Tomos/2. Moscú, Editorial Progeso, p.342.

150 'A execução dos Romanov, em Julho de 1918 definiu, como acontecera em 1793, com a descida da folha da guilhotina sobre os percoços de Luís XVI e de Maria Antonieta, preconizada por Robespierre, Danton e Saint-Just, a impossibilidade de regressar a uma página que não só fora voltada, como fora também rasgada, para que não mais pudesse ser escrita' (Rui Bebiano, Outubro, Coimbra, Angelus Novus Editora, 2009, p. 53) 
mico. Esta autonomia do político em relação ao económico, que traduz para muitos neo-marxistas uma libertação do marxismo de esquemas de interpretação evolucionistas, mecanicistas e economicistas, confere a esta obra de Marx uma inquestionável actualidade e vigor, bem expressos na constatação histórica, que é também um programa de acção futura, de que 'todas as revoluções políticas não fizeram mais do que aperfeiçoar esta máquina em lugar de a quebrar. Os partidos que lutaram à vez pelo poder consideraram a conquista desta enorme estrutura estadual como a principal presa do vencedor.'151

Ora, como se disse, o objectivo da revolução não é a simples mudança de mãos do poder político de estado. O que significa que a classe operária não deve apenas apoderar-se da máquina do estado existente, mas sim destruí-la. Nesse contexto, a Comuna surge como final do ciclo das revoluções burguesas e início da era das revoluções proletárias, salto qualitativo, prolongado e aprofundado, obviamente num quadro diferente e noutras condições, pelas revoluções russas de 1905 e 1917. Apesar da sua curtíssima duração (de 18 de Março a 28 de Maio de 1871) ela suscitou tal entusiasmo e fervor revolucionário que Marx saúda os seus heróicos protagonistas, os communards, com palavras emocionadas, pouco consentâneas com a análise objectiva de que se reclamava: 'Que elasticidade, que iniciativa histórica, que capacidade de auto-sacrifício desses parisienses. (...) A história não possui nenhum exemplo parecido com semelhante grandeza!' escrevia ele numa carta a Ludwig Kugelmann de 12 de Abril de 1817.

E, perante o massacre da Comuna, Marx poupou à condenação um movimento que alguns meses antes classificou de prematuro, para, em contrapartida, enfatizar o sentido positivo dessa experiência histórica concreta, mais importante do que centenas de programas e argumentos. Analisar essa experiência, colher dela lições de táctica e submeter à prova dos factos a sua teoria, eis a tarefa desenvolvida mais detalhadamente em A Guerra Civil em França e A luta de Classes em França.

\footnotetext{
${ }^{151}$ Karl Marx, O 18 Brumário de Louis Bonaparte, Textos Nosso Tempo, p. 143
} 
Do que se disse, e que mais não é do que uma enunciação a traços largos do que julgámos essencial para uma teoria da revolução no pensamento dos fundadores do marxismo, se pode concluir uma outra característica: a dificuldade em que as revoluções se cumpram de acordo com o quadro teórico delineado e com as condições e objectivos previstos. A dificuldade que ameaça sempre um processo revolucionário de se cumprir por inteiro, sem sucumbir às forças que do seu exterior ou mesmo do seu interior reclamam suspensões ou pausas que na prática correspondem a recuos fatais. É a clássica imagem que compara a revolução com uma bicicleta: quando deixamos de pedalar, caímos. O que significa que as revoluções concretas são sempre parciais e inconclusas, mas não experiências inúteis ou estéreis. Isto é, as experiências incompletas, parcelares e imperfeitas, se por um lado demonstram a dificuldade na concretização dos ideais, por outro não comprometem a sua bondade intrínseca e a necessidade de alargar a toda a humanidade as inegáveis vantagens que parte dela, e mesmo que só em parte, já experimentou.

Junta-se assim ao conceito de revolução total (política e social) o de revolução permanente. Ou seja, todas as expressões modernas de revolução se referem espacialmente a uma revolução mundial, e temporalmente à exigência de que seja uma revolução permanente, enquanto os seus objectivos não forem alcançados. À necessidade de a revolução ir ao fundo e ao 'cerne'152 das coisas, contra toda e qualquer atitude reformista, junta-se a necessidade da sua dimensão internacional, porque universal é a luta de classes e a divisão entre opressores e oprimidos que a justifica.

Coroação final deste modelo minuciosamente construído e prova real da sua possibilidade prática, a Revolução Russa de 1917 acrescenta assim à velha ideia de revolução o qualificativo de socialista. E mais do que socia-

\footnotetext{
152 'Mas a revolução vai ao cerne das coisas. Ela ainda só está a atravessar o Purgatório. Conduz a sua tarefa com método. Até 2 de Dezembro de 1851 não tinha cumprido mais do que metade dos seus preparativos, e agora cumpria a outra metade. Aperfeiçoa em primeiro lugar o poder parlamentar, para o poder derrubar em seguida. Uma vez atingido esse objectivo, aperfeiçoa o poder executivo, redu-lo à sua expressão mais simples, isola-o, dirige contra ele todas as censuras, para nele poder concentrar todas as forças de destruição, quando tiver concluído a segunda metade do seu trabalho de preparação a Europa saltará do seu lugar exultará: 'Bom trabalho, velha toupeira!' (K. Marx, op. cit. p.142)
} 
lista, científica. Não há utopia maior do que este projecto de uma revolução que se proclama anti-utópica. E só essa excepcional dimensão utópica e messiânica, revelação do que de melhor a humanidade foi capaz de desejar, faz com que a força de um 'Outubro ideal' sobreviva à ruína do 'socialismo real'. Como escreve Rui Bebiano, 'o facto de ter dado historicamente lugar a universos tristes e bloqueados, a regimes rudemente tirânicos, a experiências concentracionárias com o rosto negro do mal, não foi suficiente para desactivar o seu potencial criador'. ${ }^{153}$

É, pois, desse prodigioso potencial criador, muito mais do que a sombra de um sonho ou a sua mais trágica perversão, que foi a experiência histórica do regime comunista na Rússia de 1917, que falamos quando tentamos perceber aquilo que François Furet chamou o 'encanto universal de Outubro', só comparável ao que aconteceu um século antes com a Revolução Francesa de 1789. Espécie de código genético de todas as revoluções que se seguiram, 1789 e 1917 têm de comum o imenso poder de resgatar e actualizar o pathos revolucionário de qualquer tempo ou lugar.

Daí que a avassaladora produção historiográfica que inspiraram e continuam a inspirar, independentemente dos contextos sociais completamente diferentes em que surge cada uma delas, se caracterize em larga medida por um esforço de aproximação entre as duas, consagrando-as como referência e símbolo para a maioria dos fenómenos revolucionários que se lhe seguiram. Tal aproximação é sugerida e possibilitada por uma leitura da história como longo processo de libertação humana. As duas revoluções correspondem, assim, a dois momentos altos dessa caminhada: 1789 à luta pela democracia; 1917 à luta pelo socialismo. Nessa concepção há uma dinâmica de progresso que se inicia na primeira, mas que só tem pleno desenvolvimento na segunda. Assim, os discursos historiográficos sobre as duas revoluções acabam por se justificar e legitimar mutuamente. Muito esquematicamente, os bolcheviques têm os seus antepassados jacobinos, e os jacobinos foram comunistas avant-la-lettre. ${ }^{154}$

\footnotetext{
153 Rui Bebiano, Outubro, Coimbra, Angelus Novus Editora, 2009, p. 94

154 .Esta não é, no entanto, uma leitura consensual. Vários autores, entre os quais Tocqueville ou Hannah Arendt, reclamam para a Revolução Americana de 1776 um papel no trio fundador das
} 
A dimensão do impacto dos dois acontecimentos na consciência política contemporânea é tal, que torna particularmente difícil qualquer tentativa de distância intelectual. Razão pela qual as reacções que suscitam sejam ainda predominantemente de fascínio ou de rejeição. O simples vocábulo Revolução está investido de tamanha carga emocional, que torna quase impossível o seu tratamento com o mínimo de objectividade. Ou mais precisamente de isenção. ${ }^{155}$ Mas não só essa 'componente subjectiva' dificulta a tarefa de conceptualização do fenómeno revolucionário. Também a sua natureza heterogénea, espécie de precipitado de factores de ordem económica, política, social, ideológica, cultural, favorece a tentação de cada um destes domínios hegemonizar os restantes numa discutível e sempre mutável hierarquia causal. Tais respostas parcelares, provenientes de abordagens distintas do mesmo fenómeno, comportam certamente o seu grau de verdade, desde que integradas num sistema de explicação mais amplo que lhes dê sentido e valor. Mas, mesmo assim, permanece a questão: sendo esse conjunto variado de factores a razão necessária da revolução, pode

revoluções modernas, apesar da sua diminuta repercussão sobretudo na Europa. No seu famoso estudo sobre o tema Hannah Arendt considera, que todas as revoluções modernas se situam sob a influência da Revolução Francesa e denuncia como um erro histórico o esquecimento do 'glorioso exemplo' da Revolução Americana: 'Fue la Rvolución francesa, non la americana, la que pego fuego al mundo.y, en consecuencia, fue del curso de la Revolución francesa, non del de la americana, ni de los actos de los Padres Fundadores, de donde el uso actual de la palavra 'revolución' recebió sus connotaciones y ressonancias a través de todo el mundo, sin excluir a los Estados Unidos' (Hannah Arendt, Sobre la revolutión Madrid, Alianza Editorial, 2004 p. 73) .

155 Esta simples substituição de vocábulos abre para uma questão metodológica essencial que está a montante de toda a reflexão aqui desenvolvida, a qual sucintamente poderei considerar muito distante de uma leitura positivista. Nesse mesmo sentido parecem-me ir as palavras de J. Medeiros Ferreira, quando na sua obra Portugal em Transe, dedicada à nossa revolução de 1974, afirma: "sem pretender contribuir para a problemática que atormenta os historiadores sobre as possibilidades de uma objectividade perfeita peranzte os dados do passado em geral, e do passado próximo em particular, sempre me julgarei imparcial, embora possa ser atraiçoado nesse propósito pelo mais inconsciente dos subjectivismos. Ou seja, ciente das vulnerabilidades do saber histórico, não posso prometer sempre a objectividade, mas posso garantir o permanente espaço de imparcialidade" (J. Medeiros Ferreira, Portugal em Transe, in História de Portugal, dir. José Mattoso, Lisboa, Círculo de Leitores, 1994, p. 11). 
não ser a razão suficiente. Para lá das posições ocupadas pelas várias leituras, dois pontos de referência nucleares opostos balizam e orientam, mesmo à distância, toda a discussão. Um dilema a que não podem fugir os estudiosos da revolução, e que François Furet, na sua obra justamente intitulada Penser la Révolution Française, identifica com Michelet e Tocqueville. ${ }^{156}$ As perspectivas antagónicas dos dois autores ilustram paradigmaticamente esse dilema que fatalmente acompanha todo o historiador: Michelet, o poeta historiador totalmente identificado com os ideais democrático-revolucionários, representante máximo da historiografia romântica cujo herói é o povo, ou Tocqueville, o crítico liberal moderado da democracia, na lúcida e pertinente denúncia dos seus paradoxos; o acontecimento ou a sua análise. Ou ainda: a revolução que se conta a si mesma, ou que é contada por outro.

$\mathrm{Na}$ verdade, o primeiro instala-se dentro do acontecimento revolucionário que encara como corte ou ruptura radical com uma situação anterior e instauração de uma nova. Sob o modelo da identidade e da transparência, celebra a quase milagrosa coincidência entre os valores, o povo e a acção dos homens. E faz uma história fundada na experiência vivida dos revolucionários, 'une histoire sans concepts, faite des retrouvailles du cour, marquée par une sorte de divination des âmes et des acteurs'157. É, pois, uma história que vive da vertigem, da pulsão interna dos acontecimentos, encadeados por uma dinâmica própria, muito diferente da exigência racional que os enquadra, submete e organiza, quando analisados do exterior.

\footnotetext{
${ }^{156}$ Em rigor a obra não se limita à exploração do pensamento dos dois autores referidos, pois inclui um terceiro, Augustin Cochin, que o autor considera ter avançado na clarificação de algumas zonas obscuras dos seus dois antecessores: 'Le paradoxe de Cochin est que, comme Tocqueville, il se méfie des exhibitions du cœur et des spasmes d' écriture qui sont le génie même de Michelet; mais que, comme Michelet, il s' intéresse à la Révolution française comme discontinuité politique et culturelle; il cherche l'avènement torrentiel de l'idéologie démocratique, dont Tocqueville rend responsable, très en amont la monarchie administrative. Bref, il porte l'esprit déductif de Tocqueville dans la matière échevelée de Michelet. Il cherche à faire une théorie de l'événement révolutionnaire lui-même à travers le nouveau système d'action que celui-ci dévoile: il s'agit de penser le jacobinisme au lieu de le revivre' (François Furet, Penser la Révolution Française, Paris, Éditions Gallimard, 1978, p. 53).

157 François Furet, op. cit. p.32
} 
Uma dinâmica que está longe de ser linear pois que, tendo origem num encontro de vontades dos sujeitos, os transcende e ultrapassa a breve trecho fazendo deles intérpretes ou mediadores de grandes desígnios históricos, mas também vítimas directas das ondas de choque que o terramoto revolucionário sempre desencadeia. ${ }^{158}$ A história das revoluções está repleta de relatos dessa torrente revolucionária que, se por um lado 'produz em poucos dias sucessos mais importantes que toda a história anterior da humanidade' (Robespierre) e cuja heroicidade e grandeza só é comparável ao 'assalto dos céus' (expressão utilizada por Marx a propósito da Comuna de Paris), por outro faz surgir do seu interior ondas tumultuosas de refluxo que nenhum dos actores pode controlar e que os arrasta numa direcção que pouco ou nada tem a ver com os seus objectivos e propósitos conscientes. A comprovada máxima de que a revolução devora os seus próprios filhos é, apesar da banalização que sofreu, uma das mais claras ilustrações da dimensão trágica da política. A dolorosa e dilacerante proclamação do desajustamento entre o sonho e o peso da realidade. ${ }^{159}$ A revolução trans-

158 Esta contraposição linear entre Tocqueville e Michelet não recebe concordância geral. Por exemplo, Claude Lefort contesta-a, em nome de uma maior complexidade, quando escreve: 'Ora é muito mais Michelet quem deveria ser contraposto a si mesmo, se quisermos fazer-lhe justiça. Pois se é bem verdade que Michelet é um grande comungante, também não é menos verdadeiro que ele se identifica com um invisível; ele estende os braços para o todo da Revolução, porém, ao mesmo tempo, deslinda a imagem aceite de seus encadeamentos, de sua unidade, de sua positividade. É verdade que ele a comemora, mas também a julga incomemorável: ele vê-a tendo 'o vazio por monumento', como escreve no Prefácio de 1847 (seu símbolo é o Champs de Mars, 'esta areia tão branca quanto na Arábia'). É ainda verdade que ele pretende tomar furtivamente a pele dos actores, mas não é para apropriar-se dos discursos que proferem; pretende restituir o trabalho do tempo que põe em pedaços os comportamentos e as crenças, desarticula-os pouco a pouco como se fossem bonecos. Parece-nos pouco fundamentada a ideia de que ele celebra a coincidência entre os valores, o povo e a acção dos homens. Michelet faz do povo uma força omnipresente, porém latente, em nome do qual se fala abusivamente, elevando-o a sujeito ou juiz; e quantas não são as vezes em que ele observa que o povo está ausente do teatro dos acontecimentos.' (Claude Lefort, Pensando o Político ,Rio de Janeiro, Paz e Terra, 1991, p. 121/123).

159 Enquanto praxis, a política é, por excelência, a acção trágica. Na verdade, só há trágico quando há acção, quando o homem afirma a sua liberdade e não se limita a sofrer o poder de forças estranhas. Mas também quando sabe que o seu poder é limitado por circunstâncias que o ultrapassam e fogem ao seu controlo. Persistir mesmo assim na acção ameaçada, precária e contingente, caminhando entre cadeias de possibilidades, mas também de obstáculos que lhe resistem, é o que caracteriza o trágico político que, no limite, pode conduzir a acção a resultados totalmente 
forma-se assim de obra humana em processo irresistível e misterioso em que o inicial impulso de moldar, ou, pelo menos, acelerar a história, se transmuda em resignada aceitação da sua necessidade. O submeter das mais puras aspirações revolucionárias à lei férrea da necessidade ou, usando a célebre imagem de Trotsky, o 'regresso do rio ao seu leito', não resulta de uma qualquer característica essencial à revolução, uma marca ontológica, mas sim da luta sem tréguas entre revolucionários e contra-revolucionários. Ambos, por razões opostas, anseiam pelo terminar desse período a todos os títulos excepcional, como prova a consabida máxima de que não se pode viver sempre em revolução. Uns para consolidar uma nova ordem que se tem de enraizar apoiada em novas instituições, garantia necessária do êxito do acto fundador. Outros, reagindo por todos os meios ao seu alcance, aos desígnios revolucionários, através da sua imobilização ou mesmo da sua manipulação. Por isso, quando se proclama o carácter sempre inacabado das revoluções, não podemos esquecer o papel decisivo dessa dinâmica sócio-política entre forças opostas que se determinam e condicionam mutuamente. Por regra, quanto mais o cerco contra-revolucionário se aperta, mais a revolução recua para posições defensivas, que de pausas estratégicas podem deslizar para a capitulação e o malogro. Contudo, entre o 'assalto dos céus' e a descida à realidade concreta, entre o 14 de Julho (Tomada da Bastilha) e o 9 Thermidor ou o 18 Brumário, entre a tomada do Palácio de Inverno e a vitória do partido bolchevique, ou, remetendo para a nossa realidade, entre o 25 de Abril de 74 e o 25 de Novembro de 75, algo de radicalmente novo aconteceu, cuja natureza não pode ser avaliada apenas pelo resultado final. A revolução, mesmo derrotada ou desvirtuada, conserva uma espécie de invencibilidade porque permanece na memória dos povos como narrativa exaltante e inspiradora, fonte regeneradora das mais fundas expectativas de felicidade colectiva, manancial inesgotável de energias mobilizadoras contra a depressão e a decadência,

\footnotetext{
opostos aos que estavam na intenção consciente do seu autor. É o que, de forma lapidar, traduzem as palavras de J. M. Domenach: 'La politique nous ramène ainsi à la question finale que pose la tragédie: qui est coupable? Et de quoi? Et comment peut-il y avoir de la culpabilité quand le bien produit le mal, par des détours obscurs, imprévus?' (J. M. Domenach, Le retour du Tragique, Paris Editions du Seuil, 1967).
} 
'voo de águia, ou 'salto de tigre' sobre o caminhar lento e penoso de um mundo hostil e sem esperança.

Tocqueville, ao contrário, situa-se fora do acontecimento, encara a revolução sob o modelo da continuidade, e questiona justamente essa transparência ou essa coincidência, através de uma diferença essencial entre as intenções dos actores e o papel histórico que eles desempenham. A denúncia da opacidade entre a acção humana e o seu sentido real não é, como se sabe, uma ideia exclusiva em Tocqueville ${ }^{160}$ mas implica neste autor consequências que, quando consideradas em conjunto, lhe conferem grande originalidade: em primeiro lugar a referida recusa em aceitar a ideia de um corte radical, substituindo-a pela ideia de continuidade: 'Vous pensez que la Révolution française est une rupture brutal dans notre histoire nationale? dit-il à ses contemporains. En réalité, elle est l' épanouissement de notre passé. Elle parachève l'œuvre de la monarchie. Loin de constituer une rupture, elle ne se peut comprendre que dans et par la continuité historique. Elle accomplit cette continuité dans les faits, alors qu' elle apparaît comme une rupture dans les consciences'161. Nessa ordem de ideias,

${ }^{160}$ É antes, património de toda uma historiografia que pretenda englobar numa conceptualização geral a multiplicidade dos dados empíricos. Um exemplo muito claro, também analisado criticamente por Furet, é, como já referimos, o marxismo. Assim, segundo o autor, independentemente do brilhantismo das análises do jovem Marx sobre a revolução de 1789, um conceito abrangente de revolução burguesa se foi generalizando no marxismo, de certa maneira restringindo a liberdade interpretativa dos primeiros estudos, que privilegiavam o político face ao social.

A consagração de tal conceito (Revolução burguesa) serviu, pois, aos historiadores marxistas e não só, de providencial ponto de apoio que reenvia em simultâneo para o nível político, económico e social.

Ao nível político-ideológico, a revolução representa o poder da burguesia e o triunfo das Luzes sobre o obscurantismo anterior; ao nível económico liberta as forças produtivas dando origem ao capitalismo; ao nível social traduz a vitória da burguesia sobre as antigas classes e seus privilégios. Em conclusão, na base do acontecimento revolucionário, o marxismo coloca o social, ou mais precisamente, as contradições económicas e sociais, desvalorizando consequentemente os acontecimentos de natureza política e ideológica, que nessas circunstâncias excepcionais contaminam e invadem as outras instâncias. Essa desestruturação faz da revolução um acontecimento eminentemente político.

Situar a ruptura revolucionária ao nível económico e social, conduz à incapacidade de ver o que há de radicalmente novo e de mais misterioso na revolução francesa e faz dela um produto normal das circunstâncias e uma figura natural na história dos oprimidos. Ao mesmo tempo que atira as responsabilidades dos seus insucessos e desvios para os superiores desígnios da necessidade histórica.

161 François Furet, op.cit. p.33 
Tocqueville interroga-se: e se não houver neste discurso da ruptura se não uma ilusão de mudança? Que ilusões nos conta a revolução sobre ela mesma? Daí a denúncia do abismo incomensurável entre o balanço da revolução e as intenções dos revolucionários, e a crítica radical da história da revolução fundada na experiência directa dos seus actores, ou seja na tirania do vivido histórico.

Em segundo lugar, a predominância da instância do político (justamente aquela que lhe parece ter sido mais profundamente alterada pela revolução) face ao social. Ao estudar em pormenor a penetração da ideologia democrática na antiga sociedade francesa, em particular o fenómeno do jacobinismo, ele conclui que tal só foi conseguido através da dominação da sociedade civil pelo poder político, resultado directo da expansão do Estado centralizado. A centralização foi, pois, o elemento vital de uma grande revolução silenciosa que se desenvolveu em França durante o séc. XviII e se estendeu a outros países por todo o séc. XIX. É esse o traço de ligação (continuidade) entre o antigo e o novo regime, Luís XIV e Bonaparte, 'como se dessem a mão por cima do abismo da Revolução que os separa'. Por isso, a revolução, 'estado administrativo reinante sobre uma sociedade de ideologia igualitária', uma revolução feita de democracia mais centralização, foi, segundo o autor, largamente construída pela Monarquia, antes de ser terminada pelos jacobinos e pelo Império.

A questão central em Tocqueville não é, pois, saber o que muda com a revolução, mas sim o que permanece. Operando segundo um modelo que Furet chama 'révolution-contenu' (em que se faz o balanço da revolução) ele deixa de fora o seu processo específico: a 'révolution modalité, isto é 'la dynamique particulière de l'action collective qui fait que 'le bilan de la Révolution selon Tocqueville n'a pas été obtenu par une évolution à l'anglaise mais bien par une révolution. Or c'est là que réside l'événement' ${ }^{162}$. Em conclusão: a sua força é também a sua maior fraqueza. Mostrando que a revolução não é uma criação ex-nibilo, mas um prolongamento e concretização de tendências perceptíveis no Antigo Regime, Tocqueville mostra simultaneamente que a modalidade dessa concretização permanece irredu-

\footnotetext{
162 Paul Ricoeur, Temps et récit, Tome I, Paris, Etitions du Seuil,1983, p. 310
} 
tível a toda a racionalização retrospectiva. Por isso escreve F. Furet: 'Entre les origines et le bilan, entre Louis XIV e Bonaparte, il existe une page blanche que Tocqueville n'a jamais écrite, et où figurent des questions qu' il a posées, mais auxquelles il n'a pas apporté de réponse claire: pourquoi ce processus de continuité entre l'Ancien Régime et le nouveau a-t-il emprunté les voies d' une révolution? ${ }^{163}$

A pergunta que Furet coloca a Tocqueville é pois: porque é que a continuidade se fez pela via da revolução? Questão paradoxal, na contradição dos termos que encerra, mas que põe a nu o impasse a que conduz o modelo continuista, na elucidação do que há de radicalmente novo e misterioso na revolução. Ou seja, na novidade e especificidade do acontecimento revolucionário. Apesar da denúncia de tal paradoxo, Furet acaba, contudo, por cair na órbita desse modelo não só porque se mostra muito mais próximo da tese de Tocqueville de que a historiografia não pode continuar a fazer-se a partir da consciência subjectiva dos seus protagonistas (dado que nos períodos revolucionários o véu da ideologia esconde aos olhos dos actores do drama o sentido escondido dos acontecimentos) mas também pela gradual mas inevitável inclinação para o modelo crítico da revolução balanço, e finalmente, para a consequente desvalorização da crise revolucionária: 'virus d'une espèce nouvelle et inconnue', segundo Tocqueville, fenómeno de 'dérapage', segundo Furet, cujo enigma revolucionário das primeiras obras evolui para a sua patologização.

3.

Tais conceitos, bem como as novas leituras que eles possibilitam, estão na base de uma cada vez mais aguerrida e apetrechada frente crítica a que a actualidade vem submetendo a ideia de revolução em nome de um revisionismo histórico ${ }^{164}$ fortemente impulsionado por autores como Furet ou

\footnotetext{
163 François Furet, op. cit. p. 45

${ }^{164}$ Apesar de os seus antecedentes se encontrarem muito atrás, nomeadamente na própria obra de Tocqueville O Antigo Regime e a Revolução (1856), o revisionismo histórico (que outros desig-
} 
Hannah Arendt ${ }^{165}$, num crescendo que acaba por deslocar o conceito de revolução da esfera do político para o da psico-patologia. Para explicar os desastres dos movimentos revolucionários do séc. XIX e xx remonta-se à Revolução Francesa, porque nela reside a semente do mal ou da 'psicose revolucionária'. Salvaguardando as diferenças pontuais, uma lógica comum subjaz a estas leituras: condenar a Revolução Francesa, vista como um processo ruinoso que conduz à Revolução de Outubro (e do terror do período de 1793-94 ao Gulag, um século mais tarde) e às revoluções do $3^{\circ}$ Mundo. Para, em contrapartida, valorizar a Revolução Americana (1776) como normal e saudável lógica reformadora. Opera-se assim um desabamento em cadeia, segundo um processo argumentativo que, de uma forma ou de outra, acaba por percorrer os seguintes topos: deriva totalitária, ameaça dos

nam escola crítica) surge em meados do séc. xx por oposição à corrente jacobina-marxista (também designada historiografia clássica), associado à obra de Alfred Cobban (1939). Desde então tem alimentado uma produção sempre crescente que surge consagrada, por exemplo, na obra de François Furet e Denis Richet A Revolução Francesa (1965). Furet tornou-se, aliás, o maître à penser desta tendência com o citado Penser la Révolution Française (1978). O impacto desta corrente reflecte-se não apenas no âmbito académico. Domina também o discurso comemorativista do bicentenário da Revolução Francesa com a publicação de grandes obras colectivas como O Diccionário Crítico da Revolução Francesa (1988), ou A Revolução Francesa e a Criação da Cultura Política Moderna (1988), reunindo os principais adeptos do revisionismo: além de Furet, Keith Baker, Colin Lucas, Mona Ozouf, entre outros. E apresenta igualmente eloquentes manifestações na opinião pública em geral, como provam as frequentes e sensacionalistas notícias sobre a reabilitação de figuras como o último czar da Rússia e sua família, mortos pela revolução russa, ou dos descendentes de Luís XVI, morto pelos jacobinos.

165 A consagrada autora inspirou largamente a tendência revisionista do fenómeno revolucionário, nomeadamente o próprio F. Furet. A sua obra de referência, já citada, desenvolve a tese do carácter eminentemente político da revolução, em contraste com a historiografia clássica. Segundo Arendt o valor 'político' fundamental da revolução é a liberdade. E é esse o critério que a leva a concluir que, ao contrário dos americanos, os franceses fracassaram nessa tarefa, porque a erupção da violência desvirtua e perverte esse objectivo inicial. No limite a violência substitui-se à política, porque não podendo manifestar-se pela palavra, mas tão somente pela acção, ela actua fora do campo da política. É essa a grande contradição da revolução francesa e sinal maior do seu desastre. Ao contrário da revolução americana, que, como anteriormente referimos, a autora considera vitoriosa e orientadora da marcha dos povos para a democracia. Este repúdio da revolução francesa é extensível à revolução russa e tem como corolário final a condenação do comunismo soviético que encaixou ainda 'en el trágico cuadro de fracasos legado por la tradición revolucionaria francesa' (Hannah Arendt, op. cit, p. 87). Em todos os historiadores revisionistas o enfoque na violência da revolução cumpre esse objectivo: procura-se no terror jacobino os elementos de prefiguração ideológica dos totalitarismos contemporâneos, em função da fusão entre a revolução francesa e russa. 
valores constitutivos da civilização ocidental e carácter artificial (não espontâneo) das revoluções e consequente recusa da sua legitimidade social.

Esta desvalorização da ideia de revolução e do seu incalculável património simbólico, histórico e social, dominante na historiografia contemporânea, não pode desvincular-se da ofensiva política de um liberalismo triunfante que encontra no pensamento dos autores que temos vindo a analisar um poderoso aliado. Na verdade, o conflito entre revisionismo histórico e historiografia clássica (também designada corrente jacobina-marxista) só aparentemente pode considerar-se um conflito metodológico entre escolas historiográficas diferentes, pois trata-se na verdade de um conflito ideológico-político a que os historiadores não podem subtrair-se. O que no essencial separa as duas posições antagónicas é, como de uma ou doutra forma tem sido sublinhado, a questão social. Os liberais, defensores da Revolução Americana, centram a sua atenção no conceito que, tanto em Tocqueville como em Arendt, define a revolução pela ideia suprema de liberdade. Por seu lado, os pensadores de inspiração marxista colocam o acento tónico na ideia de igualdade. ${ }^{166}$ No limite, para estes, a revolução como acontecimento político/social encerra um desígnio ético de libertação das degradantes condições de vida da maioria do povo, enquanto para aqueles é uma cirúrgica aplicação de regras estritamente políticas. A preferência da filósofa Arendt pelo rigor conceptual, leva-a a afirmar com visível admiração : 'Parece como si la Revolución americana hubiese sido realizada dentro de una torre de marfil en la que nunca penetraron ni el espantoso espectáculo de la miseria humana, ni los clamores obsesivos de la pobreza abyecta'167. Abandonar a pureza dessa torre de marfim, que é o político, para sujar as mãos na imperfeita e caótica realidade do social, é

166 A Revolução Americana destinava-se à fundação da liberdade e ao estabelecimento de instituições duradouras, e a quem actuasse nesse sentido, não lhe era permitido nada que diminuísse a marca do Direito. Quanto à Revolução Francesa 'se apartó, casi desde su origen, del rumbo de la fundación a causa de la proximidad del padecimiento; estuvo determinada por las exigências de la liberación de la necessidad, non de la tiranía, e fue impulsada por la inmensidad sin límites de la miseria del pueblo y de la piedad que inspiraba esta miséria. A anarquía que representaba el princípio 'tudo está permitido' en este caso todavía procedía de los sentimientos del corazón, cuya inmensidad contribuyó a la liberación de una corriente de violencia sin límites’ (H. Arendt, op. cit., p. 122).

1671 bidem, p.126 
o que caracteriza, segundo a autora, o jacobinismo e a sua referência matricial, o sentimento de compaixão. Quando o revolucionário se deixa arrastar pelo coração para esse campo armadilhado da irracionalidade e do desespero, perde a capacidade racional de reflectir sobre as condições do político como única possibilidade transcendental de construir meios de articulação do conflito social e funções de representação da sociedade. Nessas condições, a autora opõe radicalmente revolução pura - a revolução política (e o valor da liberdade como seu fim último) - a revolução impura, ou social (e o valor da igualdade como seu fim último), remetendo para esta as responsabilidades pela interminável cadeia real (mas muitas vezes imprevisível) de obstáculos e constrangimentos, que conduzem à violência e ao totalitarismo. As revoluções têm de comum com as guerras o facto de estarem sob o signo da violência e como tal, de configurarem um tipo de acção (acção violenta) que nada tem a ver com a acção política. No fundo, a expressão revolução política encerra em Arendt uma radical contradição: se é revolução não é política, se é política não é revolução.

O que para ela distingue a acção política da revolução são afinal os meios e os fins. Enquanto a revolução tem um fim imutável que é a destruição de um determinado corpo político e a construção de um novo, segundo um modelo de necessidade semelhante ao da construção de um qualquer objecto, e com meios totalmente justificados pelos fins, a acção política tem apenas metas, linhas de orientação ou directrizes que, como tais, nunca se consideram fixas, antes de mais porque variam constantemente a sua configuração, no confronto com as dos outros. Quando a violência irrompe no espaço político, as metas transformam-se em fins, e os meios mudam também radical e drasticamente: a palavra, que configura e promove a liberdade, passa a violência, que representa no fundo o seu oposto.

Essa oposição traduz uma outra que é estruturante de todo o pensamento de Arendt: a oposição entre a ordem do político e a ordem do social. ${ }^{168}$

\footnotetext{
168 Notável helenista, a autora recua à antiguidade para detectar a origem e evolução dos conceitos, para lhes revelar o sentido que se adulterou ou mesmo desapareceu: Assim, no tempo da polis, a sociedade não existia. O mundo era dividido entre os assuntos da cidade e os assuntos do oikos. A política surge, assim, num espaço separado dos assuntos privados (onde reinam as coerções da divisão do trabalho e das relações entre dominantes e dominados), um espaço onde os homens se
} 
Só na esfera do político se pode falar de igualdade, porque a esfera do social permanecerá sempre a desigualdade. 'Infelizmente, diz H. Arendt, em substância fomos constrangidos a confundir igualdade política com igualdade social; confusão trágica, pois igualdade só pode ser política; confusão que é, aliás, filosoficamente traduzida por uma ideia insensata, segundo a qual os indivíduos são iguais por nascimento: a quimera dos direitos do homem. É forçoso assinalar que, para H. Arendt, como para Burke, só são reais os direitos dos cidadãos, e os direitos do homem são uma ficção,169. A expansão do social é a degradação da política e, portanto, a revolução consiste numa tentativa de regresso da política e do triunfo do político sobre o social. O problema é que a maior parte delas se deixam contaminar pelo vírus igualitário que se quer estender ao domínio social, quando a sua esfera será sempre apenas a do político.

As teses de Arendt esbarram com dificuldades internas e externas ao seu próprio pensamento. Internamente parece haver uma contradição insanável entre esse rigor (para os seus críticos muito próximo da arrogância) conceptual, por um lado, e a reiterada desconfiança da autora em relação a teorias que sempre fixam o singular a partir do reino dos princípios. ${ }^{170}$ Externamente

reconhecem como iguais, discutem e decidem em comum. O poder exerce-se aí como uma troca de falas, com vista a decisões que concernem a todos. A própria existência desse espaço é a condição do aparecimento de um 'mundo comum', um mundo que não é UM, mas se mostra como o mesmo, porque vive da multiplicidade de perspectivas. Só com a modernidade se dá o aparecimento do social, com o papel crescente do estado (séc. xıx e xx), como responsável pela sua gestão. Com o desenvolvimento da técnica, da ciência e da divisão do trabalho, institui-se uma rede geral de dependência que mantém os indivíduos agrupados sob as actividades e necessidades, implica tarefas de organização cada vez mais complexas e induz a relação de dominação na nova escala da Nação. Em conclusão, com o advento do social, a politica perde o seu estatuto. Desaparecendo o espaço público, desaparece consequentemente o espaço privado. A oposição não é já, pois, entre político e privado. É sim, entre organização social e mundo da intimidade que se torna algo ilusório, sujeito à estandardização dos costumes e dos comportamentos.

169 Claude Lefort, op.cit. p. 71

${ }^{170}$ A recusa de Arendt em considerar-se filósofa radica justamente no laço profundo que, segundo ela, existe ou dever existir entre o pensar e o acontecimento. E parece óbvia, em toda a sua obra, uma tensão constante entre o desejo de elaborar uma teoria e a vontade de abertura ao acontecimento. Pensar não significa, para a autora, mover-se no já pensado, mas 'recomeçar através das provações impostas pelo acontecido' como lembra na obra Between Past and Future. A afirmação tantas vezes repetida de que se trata de compreender a acção política demarca-a quer da filosofia 
a sua tese sobre a Revolução Americana sai ferida do fogo cruzado a que a submetem pensadores como Domenico Losurdo quando põe a nu a abstracção das categorias que consagram a sua pretensa 'pureza' denunciando essa mesma revolução como lugar da liberdade, num país em que florescia a escravatura, a segregação racial e uma política de massacre e de deportação em relação aos índios. Assim, para o autor, um pensamento que conduz a tais resultados está mais próximo da metafísica do que da história, concluindo: 'lo storico della filosofia o delle idee deve ricostruire la trama storica reale dentro la quale vengono formulate determinate idee, che quest' ultime vanno sottoposte ai vaglio dei clima e dell' ambiente storico in cui nascono, prima di avere la pretesa di affermarsi sub specie aeternitatis'171. Assim, fiel ao método marxista de análise dialéctica da realidade histórica, Losurdo questiona as categorias arendtianas de violência e totalitarismo como abstracções teóricas que, acentuando as muitas semelhanças entre a França de 1789 e Rússia de 1917, ignoram as equivalentes diferenças, isto é, as particulares condições históricas concretas da erupção do fenómeno revolucionário em cada um destes momentos. Fazer esta generalização teórica de largo alcance, através de um único traço comum com a carga negativa do totalitarismo, significa condenar genericamente a revolução por ter sacrificado a sua matriz originária - o valor supremo e inalienável da liberdade - substituindo-a pelo valor da igualdade, ou, dito de outra forma, por ter abandonado a 'torre de marfim' dos puros princípios políticos para se envolver no mundo concreto dos homens com a sua intrínseca dramaticidade. Também Toni Negri critica

política, quer das ciências sociais. É este afinal, o impulso que a leva a não desistir de compreender o totalitarismo, conceito que na sua obra mais conhecida, As Origens do Totalitarismo, se aplica igualmente ao nazismo e ao comunismo. Nesse sentido se pode considerar a sua teoria da política como uma espécie de fenomenologia. Contudo o que alguns críticos questionam é se tal tensão entre o pensar e o acontecer não acaba por ceder ao peso dos conceitos e da teorização. É dessa dimensão dilemática da obra que fala M. A. Hill: 'En su obra Hannah Arendt crea un espacio en el que uno puede caminar con la magnífica sensación de acceder, a través de un pórtico, a una área libre pero, en buena parte, ocupada por definiciones... Este hábito de establecer distinciones no es popular en el mundo moderno, en el que la mayoría de discursos están rodeados por una suerte de contorno verbal borroso' ( in Hanna Arendt, Que es la política, Paidós I.C.E /U.A.B, 1997).

${ }^{171}$ D. Losurdo, La Comunità, la morte, l'occidente-Heidegger el'ideologia della guerra. Ed. Bollati Boringhieri, p. 172 
com veemência as concepções de Arendt que, segundo ele, aliam um altivo intelectualismo com um cinismo sócio-político: 'libertad americana contra liberación jacobina. La Arendt connota creativamente este paso; la revolución constitucional es un gallardo mozo que aparece para renovar el mondo con fuerza pura y espontânea y non por conmoción degradante. De un golpe, el mito de la virgiliana Egloga IV y el tocquevilliano del individualismo americano se despiertan bajo el mismo tecto' ${ }^{172}$. Assim, o autor considera que ao indicar como modelo alternativo a possibilidade de uma organização constitucional, Arendt contrapõe ao espaço político 'conmoción-terrorismo', um novo que ele designa 'cinismo-parlamentarismo', e que mais não é do que um falso momento constituinte, definido justamente a partir da ordem constituída, a qual fixa os limites da libertação a partir das condições estruturais da liberdade, quer como representação política, quer como progressiva expansão do direito. O real só pode então ser captado dentro dos quadros de procedimentos pré-estabelecidos adequados à finitude do existente e à multiplicidade das liberdades. A sua racionalidade jamais deve ser contaminada pela sensibilidade social de um presente em chamas. ${ }^{173}$ Contudo, só um estéril intelectualismo pode sustentar ser possível a separação rígida entre razão política e irracionalidade social. A fenomenologia política de Arendt, nos seus bloqueios e contradições metodológicos por um lado, e pressupostos ideológicos por outro, mascara, afinal, a constatação de que uma só existe para e com a outra, alimentando o ciclo vicioso dos opostos. 'Como evitar el terrorismo, si la vía del parlamentarismo no es transitable? La búsqueda de una alternativa se prepara desde un primer reconocimiento: tanto el terrorismo como el parlamentarismo son el producto de una misma máquina, aquella representativa de la sociedad disciplinaria'174.

\footnotetext{
172 Toni Negri, Fin de Siglo, Barcelona, Paidos/I.C.E. - U. A. B. 1992, p.156

173 'La tentación jacobina es actual. Ella se renueva cada vez que la compasión emerge como pathos de la época. Como no padecer con los muchachos da la Intifada masacrados con el tiro al plato del opresor, o con los civiles iraquíes asesinados por las tecnologías más limpias? Como non reconocer en el terrorismo la única forma de resistencia a un orden asfixiante, sistematizado, centralizado en el mando internacional?'(Toni Negri,op.cit. p. 155).

${ }^{174}$ Ibidem, p. 160
} 
Em contexto nacional, e no caso concreto da nossa revolução de 1974, esse fenómeno de generalizado abandono da ideia de revolução não deixa também de se verificar. Segundo José Medeiros Ferreira tal acontece devido a duas ordens de factores que podemos classificar de ordem interna e de ordem externa. Os primeiros relevam das concepções estruturais que dominam a prática historiográfica actual. Habituados ao estudo de tempos longos e contínuos e de estruturas que mudam muito lentamente, a maior parte dos historiadores experimenta sérias dificuldades em enquadrar essas rupturas brutais e violentas que em dado momento desestruturam todo um sistema sócio-político, subvertem modos de viver e de pensar, instalam o desconhecido onde antes era o domínio da normalidade e da previsibilidade. 'A história quantitativa dos grandes espaços e a história nacionalista e regional conjugaram-se para desviar os historiadores do conceito de revolução e da importância a atribuir às rupturas. Procuram-se mais as continuidades do que as diferenças. Daí que, hoje em dia, qualquer diferença, qualquer evolução do statu quo nacional e internacional apareça como uma surpresa que ninguém previu. A História como foi feita e ensinada nos últimos cinquenta anos não permite entender o que é uma revolução. 175

Os segundos prendem-se, por um lado, com a referida questão mais vasta do triunfo do modelo liberal, que veicula fórmulas como 'o fim das ideologias' ou o 'fim da história', as quais moldam as ciências sociais em geral segundo uma concepção unidimensional restritiva e estéril; e, por outro, com a própria expansão do conceito de revolução, o qual, na sua enorme elasticidade e ubiquidade, acaba no século xx por penetrar em todas as esferas do quotidiano (revolução científica, técnica, industrial, de costumes). Contudo, este alargamento do seu campo de utilização é a outra face de uma diluição do conceito, da sua fuga para zonas periféricas e, consequentemente, da perda das suas características essenciais. 'Hoje emprega-se o termo revolução para designar outros movimentos noutros

\footnotetext{
175 J. Medeiros Ferreira, Portugal em Transe, História de Portugal, dir. José Mattoso, vol 8, Lisboa, Círculo de Leitores,1993, p. 7
} 
“Revolução” e Revisionismo Historiográfico. O 25 de Abril Visto da História

campos. Temos, por exemplo, a revolução tecnológica, a revolução das telecomunicações, ou a revolução informática. Enquanto isso acontece, os historiadores tornam-se cada vez mais parcimoniosos na utilização do conceito que, sem saída no seu meio mais familiar, emigra para saberes mais sensíveis às transformações contemporâneas'. 176

Em conclusão, nos nossos dias um padrão hegemónico de análise e prática social proclama que a ideia de revolução entrou em crise. Como se o século que se iniciou com a própria ideia de revolução, no exacto sentido de que o mundo vai mudar de base, terminasse com a solene proclamação da sua impossibilidade. As suas grandes linhas de argumentação são, muito resumidamente, as seguintes:

Em primeiro lugar a revolução é vista como um anacronismo ou mesmo uma impossibilidade histórica. Considerando o processo económico e social do capitalismo como objectivo e fatal, portanto de acordo com a ordem natural das coisas, qualquer tentativa de lhe alterar o seu curso normal é anatemizada com o selo do voluntarismo e do totalitarismo. Daqui decorre que o horizonte de possibilidades transformadoras é significativamente reduzido a pequenas operações de ajuste e correcção.

Em segundo lugar, partindo da ideia de que todas as revoluções são vencidas, ou no mínimo interrompidas, com custos incomparavelmente maiores do que os ganhos, conclui que a diminuição das diferenças sociais só ocorreu por meio de reformas, enquanto a revolução só serve para as agravar. Tais argumentos são, contudo, desmontados por todos quantos se não submetem à ditadura do pensamento único e denunciam a enorme carga ideológica de um modelo que celebra a vitória do capitalismo, tornado sistema mundial hegemónico e pretenso estádio final da história humana.

Por outro lado, a avaliação dos resultados catastróficos da revolução no que respeita às conquistas sociais esbarra com a constatação histórica de que a diminuição das diferenças sociais só ocorreu por meio de reformas, quando se verifica a combinação excepcional de dois factores: desenvolvimento económico e receio perante a possibilidade de uma revolução. Só então o

\footnotetext{
${ }^{176}$ Ibidem, p. 7
} 
capital aceitou negociações com o trabalho. ${ }^{177} \mathrm{Na}$ verdade, é uma constante através dos tempos, as estratégias do poder instituído perante a ameaça de revolução consistem em a fazer abortar ou, perante essa impossibilidade, em a manipular. E a maior manipulação consiste justamente na máxima de que o tempo das revoluções acabou. Ora, como conciliar essa morte anunciada pela ideologia dominante, com a demonstração, que estudiosos como André Glucksmann fazem, de que todo o século xx é atravessado 'de révoltes inattendues pour les pouvoirs en place (soulèvements anticoloniaux, résistances antifascistes, insurrections antisoviétiques des populations de l'Est')? ${ }^{178}$.

A sentença de morte a que os seus adversários a condenaram, parece então contrariada de forma brutal pelos factos. Certamente que as novas revoluções, apesar da forte herança que recebem daquela que indubitavelmente inaugurou e marcou todo o século xx, a Revolução Russa de $1917^{179}$, assumiram características próprias que as afastam do modelo original. Não por acaso o termo revolução é frequentemente substituído por revolta. Por muito que tenham de comum algo as distingue claramente: a visão holística da revolução, face a uma perspectiva mais fragmentária e parcelar da revolta. O projecto de uma revolução científica, radical e final, face a um levantamento mais espontâneo e localizado. Partindo de uma situação se-

177 Como escreve André Glucksmann, 'les révoltes font la force productive de l'histoire moderne. Pas seulement les révoltes des ouvriers anglais, qui forcent, par contrecoup, l'accélération du développement technique et capitaliste. Aussi bien les révoltes américaines de 1930, qui entrainent un virage dans les rapports entre les différents secteurs de la production, engendrant la production massive des moyens de consommation qu'on nomme abusivement 'société d'abondance'. En limitant le taux de chômage supportable par une société moderne, les luttes qui accompagnèrent la grande crise économique de 1930 ont infléchi toute la vie économique, réorienté les investissements, etc. Les révoltes anti-guerres du Viêt-Nam et résistance des contestataires russes risquent également d'exercer leur influence jusque dans cette 'base économique' que les experts marxiste et libéraux pensent à mille lieues des remous 'psychodramatiques' des révoltes actuelles' (André Glucksmann, Histoire des Idéologies, dir. François Châtelet, Hachette,1978, p. 364).

178 Ibidem, p.349

179 'O mundo que se esfacelou no final dos anos 80 foi o mundo formado pelo impacte da Revolução Russa de 1917. Fomos todos marcados por ela, por exemplo, na medida em que nos habituámos a pensar na moderna economia industrial em termos de opostos binários, capitalismo e socialismo, como alternativas mutuamente excludentes, uma identificada com economias organizadas com base no modelo da URSS, a outra com todo o restante'. (Eric Hobsbawm, A Era dos Extremos, Lisboa, Presença, 2002, p. 16). 
melhante, de ruptura e contestação, não ambicionam o mesmo ponto de chegada: 'les révoltes ne posent pas de but en blanc la question du pouvoir, elles défendent simplement la manière propre par laquelle une collectivité résout ce problème ailleurs - mythologiquement, structuralement, plus ou moins inconsciemment, voire démocratiquement. On se révolte pour pouvoir poser la question du pouvoir, non pour la résoudre. Se donner les moyens de la question ne revient pas à imposer une réponse' ${ }^{180}$.

Assim, se todas as revoluções começam pela revolta, nem todas as revoltas acabam em revoluções, se por tal se entender a organização final de um novo poder segundo uma teoria revolucionária e através de um movimento revolucionário. O marxismo-leninismo operou essa passagem delineando o novo mundo e com ele o novo homem, através de uma ciência da revolução. Entramos assim no reino da necessidade e, portanto, na recusa do carácter interminável e imperfeito de todas as revoltas. Se falar da crise da ideia de revolução significa, pois, falar da falência histórica desse modelo de revolução científica, e das consequências inesperadas, indesejáveis e trágicas desses projectos humanos colectivos do séc. Xx, muitos pensadores, mesmo de inspiração marxista, poderão concordar. E mais do que isso, deverão tentar compreender, à semelhança de Eric Hobsbawm, por que é que isso aconteceu. Entretanto a realidade social e politica, na sua dramática divisão entre forças que agem no sentido da mudança e forças inibidoras, continua a ser terreno fértil de sementes revolucionárias. 'A condition d'abandonner les oillères idéologiques des révolutions finales et des contre-révolutions apocalyptiques, on découvrira dans les révoltes sociales, intellectuelles et culturelles, ni tout, ni rien, un ressort de l'histoire, le sel de la terre' ${ }^{181}$.

\section{5.}

Embora com as especificidades próprias que sempre teremos de acautelar ao aplicar a generalidade das grandes linhas interpretativas a contextos par-

\footnotetext{
${ }^{180}$ André Glucksmann, op. cit. p. 357

${ }^{181}$ Ibidem, p. 365
} 
ticulares e, portanto, sem poder afirmar que também temos o nosso Michelet e o nosso Tocqueville, os modelos de análise representados por cada um deles, pelo seu carácter paradigmático, parecem-me extremamente úteis e sugestivos para clarificação das tendências dominantes na historiografia da nossa revolução de 1974. Na verdade, e sem deixar de sublinhar que toda a sistematização exemplificativa é sinónimo de simplificação, acreditamos que esse recurso tem a vantagem de colocar em evidência os traços fundamentais comuns às transformações revolucionárias em geral, e, consequentemente, às respectivas tentativas de explicação.

Começando pela tese da continuidade de Tocqueville, o paralelismo torna-se flagrante se substituirmos a expressão "évolution à l'anglaise” por "evolução à espanhola". Na verdade, é já um tema clássico da historiografia portuguesa $^{182}$ o estudo comparativo entre a nossa revolução e a transição espanhola. Não sendo este o momento para o desenvolvimento que esta temática merece, não deixa contudo de parecer oportuno avaliar, mesmo que de forma abreviada, as ideias força dessas análises comparativistas, bem como o seu impacto no conjunto da historiografia do 25 de Abril. Antes de mais, parece-nos uma tendência dominante nesses estudos a valorização da via reformista espanhola, por oposição à consequente desvalorização da via revolucionária portuguesa. Nos trinta e seis anos que levamos de democracia, tudo parece contribuir para essa espécie de contabilidade das perdas e danos, salientando que tudo seria diferente para melhor, se tivéssemos feito como os espanhóis que, aliás, muito aprenderam connosco, se não pela positiva, pelo menos pela negativa, isto é, vendo no nosso exemplo aquilo que não deveriam fazer.

\footnotetext{
182 Como salienta Fernando Rosas no artigo A revolução Portuguesa de 1974/75 e a institucionalização da Democracia, in Manuel Loff e M. da Conceição Meireles Pereira (coord), Portugal: 30 Anos de Democracia (1974-2004), Porto. Editora da Universidade do Porto, 2004, "a sua influência, pelo menos no processo de transição para a democracia em Espanha, após a morte de Franco, em 1975, parece ser hoje inegável, a despeito do quase silêncio que sobre isso guarda a maioria da historiografia espanhola". Com a excepção, aliás assinalada pelo autor, constituída pelo catalão Josep Sanchez Cervelló, autor da primeira obra académica em contexto peninsular sobre a revolução portuguesa e sua influência em Espanha. Trata-se da obra A revolução portuguesa e a sua influência na transição espanhola, Lisboa, Assírio e Alvim, 1993.
} 
A tese vem ganhando, obviamente, cada vez mais adeptos à medida que nos afastamos em todos os sectores dos ideais de Abril, inseridos num sistema que os declara pela prática diária definitivamente enterrados. ${ }^{183}$ Essa leitura (do balanço em prejuízo do processo) parte, como disse, de uma condenação sumária da revolução, que, como um mal em si, haveria a todo o custo que evitar. Se há condenação, há condenados, e os principais serão, curiosamente, não só os revolucionários pela acção desencadeada, mas também os governantes de então, por omissão, isto é, por não a terem evitado: Marcelo Caetano e os sectores liberalizantes que o apoiavam. A sua incapacidade em capitalizar a onda de apoio de que beneficiou no início do seu consulado, no sentido de uma abertura democrática está, segundo esta tese, na origem do 25 de Abril. Uma reforma nesse sentido, semelhante à que ocorreria mais tarde em Espanha, seria possível (e desejável), não fora a inépcia, o medo, o cansaço ou o excesso de zelo das forças de bloqueio de então. A reforma do regime deveria pois não só assegurar as liberdades fundamentais, como permitir a negociação, em posição de força, da autodeterminação das chamadas províncias ultramarinas. De aqui até à tese de que, "com 25 de Abril ou sem 25 de Abril estaríamos como estamos, ou até melhor", vai um passo. O mesmo que leva à concepção da revolução como um parêntesis dispensável ou um irritante contratempo. O poder político e económico que a chamada Ala Liberal do Antigo Regime vem a recuperar depois da estabi-

183 Pela prática, que não pelo discurso, uma vez que tudo o que se tem feito contra o 25 de Abril é ainda em nome dele mesmo. Na verdade, uma das contradições estruturantes da nossa personalidade cultural, que o 25 de Abril longe de anular, antes potenciou, é a facilidade com que anulamos o conflito através do expediente psicanalítico da denegação. Falar constantemente do 25 de Abril, para mais facilmente o esconjurar. As consequências estão à vista, se tivermos em conta o contraste brutal entre o discurso dos políticos e a realidade dos factos. É certamente esta uma das causas da debilidade da democracia portuguesa: a falta de civismo, o desinteresse democrático, o continuado atraso social, económico e cultural. Um ambiente de cinismo generalizado contamina não só a classe política como a sociedade em geral. Até porque muitos dos que consideram os políticos uns aldrabões, são precisamente aqueles que, tendo acreditado em si mesmos entre Abril de 74 e Novembro de 75 , se viram pouco a pouco confrontados com o desabar do sonho, do qual fica apenas a linguagem. 
lidade institucional, desenterra a tese da "evolução na continuidade". ${ }^{184}$ O tempo atenua os conflitos e, já sem Marcelo mas com os marcelistas de hoje, é possível a criação de uma "história-ficção" que situa a génese da democracia actual justamente no processo de liberalização iniciada ainda no interior do antigo regime. Processo que, bloqueado pelos ultras, acaba por ressurgir por uma espécie de artimanha da história.

O longo processo político-legislativo contra-revolucionário, certamente ainda não concluído, pode até explicar essas versões revistas e actualizadas, mas não as justifica no plano do rigor histórico, uma vez que faz tábua rasa do processo revolucionário e do imenso espaço de possibilidades de mudança que ele proporciona. Portanto, entre as origens (crise ou bloqueio do marcelismo) e o resultado final (a concretização de promessas liberalizantes anteriormente anunciadas) fica tudo por saber sobre o tempo revolucionário, as forças que desencadeia, os dinamismos que dele emergem. Porque, como lembra Fernando Rosas, "A revolução de 1974/75 (...) durante os 19 meses que durou, entre 25 de Abril de 1974 e 25 de Novembro de 1975 procuraria mudar de forma radical a face económica, social, polí-

${ }^{184}$ Vale a pena recordar o polémico episódio em torno das comemorações dos 30 anos do 25 de Abril, que a comissão nomeada para o efeito, presidida pelo historiador António Costa Pinto, entendeu subordinar ao tema "Abril é evolução" e que nos parece ser o exemplo perfeito de manipulação da história no sentido de que falamos. Na verdade, esta iniciativa do poder político de então (governo PSD/PP) invertendo o normal figurino das comemorações, habitualmente reduzidas a pálidas evocações da festa revolucionária, e a uma engravatada sessão solene na Assembleia da República, levou a cabo a mais ambiciosa mistificação histórica: anulando o passado revolucionário, e celebrando o presente neo-conservador e neo-liberal efectuou uma complexa operação de marketing, situada algures entre a amnésia e a mentira.

Amnésia, porque ignora que a democracia nasceu justamente de uma revolução e não de um qualquer continuismo liberalizante; que essa democracia foi conquistada por um corte violento com o passado de ditadura. Mentira, porque o 'celebrado' progresso ou evolução se fez (se vem fazendo) segundo um modelo que não prolonga nem aprofunda os valores de Abril, antes é feito ao arrepio de muitas das suas promessas e esperanças. Contrapõe-se, assim, revolução, diabolizada ou minimizada como epifenómeno ou crise insignificante, e democracia, numa operação de propaganda ideológica, sem qualquer sustentação histórica, legitimando um caminho para a sociedade portuguesa que passa pela liquidação de uma parte essencial do património de conquistas sociais, culturais e políticas, iniciadas em 74 e consagradas constitucionalmente em 76. Amnésia e mentira são, pois, em termos psicanalíticos, a forma como o regime democrático lida com esse trauma silencioso que é o 25 de Abril. Mesmo que o comemore, ou justamente porque o comemora para mais facilmente o esquecer. 
tica e cultural do país. E a democracia institucionalizada em 1976, fruto, é certo, da sua contenção, é por ela genética e decisivamente marcada. É uma democracia que sai, apesar de tudo, do processo revolucionário e não, como pretende a revisão conservadora do período, que se imponha contra ela". ${ }^{185}$

Contudo, é esta visão conservadora denunciada por F. Rosas, a predominante na actual historiografia sobre o 25 de Abril. Predominante, mas não exclusiva. Na verdade, ela interrompeu o esforço de alguns historiadores que nos anos seguintes à Revolução, apesar da enorme carga de incerteza e até de ambiguidade, demonstraram real sensibilidade para a excepcionalidade do momento histórico que o país vivia e para a necessidade de o pensar como ruptura com um tempo passado e instauração de outro radicalmente novo. Num aturado e minucioso exame dessas tentativas feito por Addoolkarim Vakil $^{186}$ se analisam os nem sempre coincidentes discursos das elites nacionais na produção de um novo discurso identitário que corresponda à 'viragem histórica'187, assim consagrando no Preâmbulo da Constituição de 1976 a noção de que 'libertar Portugal da ditadura, da opressão e do colonialismo representou uma transformação revolucionária e o início de uma viragem histórica da sociedade portuguesa'. ${ }^{188}$ O autor assinala, assim, nesse esforço duas linhas essenciais. Uma primeira em que o discurso é marcado por intervenções de forte empenhamento que procura enquadrar o 25 de Abril numa verdadeira mudança de paradigma cultural e cívico. A identidade nacional é vista, pois, como 'sinónimo de imagem-projecto histórico da comunidade a qual, em momento de refundação, procura moldar em termos de uma visão política para o Portugal do pós-autoritarismo e pós-descolonização.' ${ }^{189}$ É a fase da intervenção activa e militante de intelectuais e historiadores por um lado e de políticos pelo outro. Os primeiros procuram repor a questão da

\footnotetext{
185 Fernando Rosas, op.cit, p. 21

${ }^{186}$ Abdoolkarim Vakil, Heróis do Lar, Nação Ambivalente. Portugalidade e Identidade Nacional nos tempos dos Post. In Portugal: 30 Anos de Democracia (1974-2004), Coord. Manuel Loff e M. da Conceição Meireles Pereira. Porto, Editora da Universidade do Porto, 2006.

187 Curiosamente é este o título dado pelo estratega Otelo Saraiva de Carvalho ao plano de Operações que elaborou para as acções militares desencadeadas com vista ao derrube da ditadura.

${ }^{188}$ Abdoolkarim Vakil, op. cit, p. 85

189 Ibidem, p. 88
} 
narrativa histórica em Portugal segundo o modelo predominante do re-encontro de Portugal consigo próprio depois de cinco séculos de alienação da sua personalidade política nacional. A ideia do fim do ciclo do império, quer se traduzisse na linguagem crua da tragédia do colonialismo, quer na sugestiva metáfora do regresso das caravelas, era o leit-motif dessa nova historiografia, que apontava ao mesmo tempo para o necessário esforço de reterritorialização ou de re-centramento deste pequeno país ausente de si mesmo durante a maior parte da sua história multisecular. Victor de Sá, António Borges Coelho ou Magalhães Godinho são os mais activos e empenhados historiadores cuja reflexão não deixou de 'contaminar' o discurso dos políticos. Um regresso às suas intervenções em comícios, encontros, sessões oficiais, além de abundante produção escrita, mostra a preocupação sempre presente de produzir uma nova narrativa identitária, num primeiro momento mais exaltante e glorificadora, logo seguida de uma outra mais realista, em que a ideia de crise regressa como dominante e central. ${ }^{190}$

O discurso da crise (de identidade e outras) regressou cedo, para não mais nos abandonar, o que exige uma reflexão interdisciplinar que, apesar de apaixonante, não cabe nos limites deste trabalho. Por outro lado, os nossos Michelets, ou os que dessa designação mais se aproximaram, foram injustamente esquecidos, o seu esforço interrompido, perdendo em toda a linha para os Tocquevilles caseiros. Consagra-se assim uma corrente continuista da qual, a título de exemplo, salientarei a recente, e unanimemente

\footnotetext{
190 O autor considera que é sob o signo da crise da identidade nacional que se desenvolve a actividade política a partir de 76 , a começar no $1 .^{\circ}$ Governo Constitucional e a alargar-se a todos os sectores políticos representados no Parlamento. O programa desse mesmo governo declara como principal linha de actuação 'vencer a crise, reconstruir o país', o qual por sua vez se definia como 'Portugal reduzido aos seus limites europeus'. Na mesma linha, Mário Soares, no discurso de apresentação formal do programa ao Parlamento utiliza o termo crise doze vezes em três curtos parágrafos. Também Sá Carneiro e Lucas Pires no debate que se segue concordam, com diferenças não significativas, na ideia de que se vive uma crise de identidade nacional. O mesmo vem a acontecer, mais tarde, já em 1977, no discurso do 1. ${ }^{\circ}$ Ministro à Assembleia da República, em apresentação da proposta de adesão à Comunidade Europeia. E já no Programa do 2. ${ }^{\circ}$ Governo Constitucional em 78, é ainda de crise que se fala, embora ela agora se centre no plano mais concreto da economia, com a Europa como horizonte: 'Da redução geográfica e económica de Portugal aos seus limites europeus, em consequência do fenómeno histórico e inelutável da descolonização - o país procura uma nova identidade' (Abdoolkarim Vakil, op. cit. p. 83).
} 
consagrada, História de Portugal de Rui Ramos. ${ }^{191}$ Salvaguardando o facto de, por motivos óbvios, o 25 de Abril ser resumidamente tratado (praticamente apenas nas 40 páginas do cap. X ) ficam, mesmo assim, muito claras as opções do autor pela tese da 'evolução na continuidade'. A revolução é totalmente desvalorizada, ${ }^{192}$ inserida numa certa 'normalidade portuguesa' que esconde o carácter único e excepcional do fenómeno revolucionário e o reduz a um episódio secundário sem consequências de maior. Privilegiando o tempo longo e contínuo, e as estruturas que mudam muito lentamente, o tempo curto mas intenso e saturado de acontecimentos (bem diferentes dos fait-divers em que por vezes a escrita ágil de Rui Ramos os transforma) da revolução dilui-se nos múltiplos indicadores aparentemente neutros da evolução da sociedade portuguesa num amplo arco temporal que o autor situa entre 1961 (considerado como início de um decisivo movimento reformista ) e 1997 (ano em que Portugal se torna oficialmente um 'pais desenvolvido'). São afinal trinta e seis anos de firme progresso para uma democracia europeia, nos quais os breves dezanove meses de revolução pouco mais foram do que um sobressalto ou um desvio de rota a tempo corrigido.

\section{6.}

Ainda neste esforço de pensar a revolução, e contemplando apenas as correntes quanto a nós mais significativas, ${ }^{193}$ importa considerar uma outra

\footnotetext{
${ }^{191}$ Rui Ramos (coord.), Bernardo Vasconcelos e Sousa, Nuno Gonçalo Monteiro, História de Portugal, Lisboa, A Esfera dos Livros, 2009.

${ }^{192} \mathrm{E}$, por vezes até olhada com um misto de paternalismo e ironia, como quando escreve: 'Para consolidar a chamada 'aliança povo-MFA 'a História do 25 de Abril foi reescrita como uma 'revolução de capitães', logo transformada numa 'revolução popular' cujo destino final só podia ser um: o socialismo'.(op. cit. p. 718); quando, a propósito da adesão popular, cita a GNR : 'Foram estudantes e rapazes quem começou por festejar as tropas' ( op. cit. p. 713); ou ainda, quando, a propósito das complexas relações de Spínola com os capitães, afirma:' Embora nunca pudessem ter feito o golpe sem Spínola, criaram a ideia, depois geralmente aceite, da 'revolução dos capitães' usurpada por um general' (op. cit. p. 715).

193 Não consideramos aqui, por não lhe reconhecermos estatuto histórico, mas apenas miliância político-ideológica, a corrente radical de diabolização da revolução por que é responsável uma direita saudosista que tem surgido ultimamente com surpreendente à vontade nos meios
} 
em quase tudo diferente da anterior, mas conducente a um resultado muito semelhante, ou seja a uma incapacidade em pensar o processo revolucionário no seu conjunto como implosão de determinado edifício social e político, e consequente emergência de perspectivas de substituição muito diferentes e até opostas. Contudo, essa incapacidade não resulta, como no primeiro caso, de uma qualquer suspensão histórica da revolução, antes de uma clara consciência da sua importância, como fundadora de algo novo e diferente. Com uma ressalva: a revolução é aqui encarada não globalmente, como realidade total, mas antes como meio através do qual, por entre acertos e desacertos, avanços e recuos, um caminho se impõe a todos os outros, marcando o seu desfecho, e legitimando-se assim retrospectivamente. Considera-se, pois, que a construção da democracia, longe de ser um prolongamento ou uma concretização de vagos ideais liberalizantes pré-existentes à própria revolução, foi antes obra de forças e protagonistas dela emergentes, e segundo um plano que de alguma forma os transcende, porque inscrito na longa marcha da história no sentido do progresso. Assim, apesar de todas as derivas e desvios, há como que uma lógica interna a guiar os acontecimentos no sentido de um determinado desfecho. Se no primeiro caso há um artifício da história neste há uma quase perfeita execução do seu plano, já conhecido e abalizado, aliás, pelo

académicos e mediáticos. Apostada em primeiro lugar na reabilitação de Salazar, e de seguida no branqueamento do seu 'Estado Novo', assistimos a uma verdadeira operação de propaganda que vai desde a publicação de livros e artigos, a um ritmo surpreendente, até a concursos e programas de televisão em que deliberadamente se esconde o lado mais terrível da ditadura. Afinal o ditador responsável pela guerra colonial e seus massacres, pela censura, pela repressão, prisão, tortura e morte dos opositores, pelas farsas que eram os seus julgamentos, pelos saneamentos e expulsões da função pública, pelos campos de concentração como o Tarrafal, pelo medo como fonte da ordem e da autoridade, era afinal, na vida privada um cavalheiro afável e cheio de charme, e em público um notável estadista... A onda salazarista que atingiu o ponto alto, em 2007, com a vitória do ditador no concurso Grandes Portugueses da televisão pública, parece longe de se esgotar e os media aproveitá-la-ão enquanto vender. Ultimamente a criatividade dos publicitários surpreendeu mais uma vez, ao anunciar uma nova publicação sobre o ditador com frases como 'Nem bom nem mau, incontornável', 'Será a história como a pintam?' e em que a imagem de Salazar deixa de ser como sempre a preto e branco, para se transformar numa autêntica estrela pop: cabelo azul, casaco vermelho ,ou o contrario, numa onda de cor que não deixará de convidar a uma revisão da clássica imagem do homem vestido de escuro, chapéu enterrado na cabeça e botas de elástico. Afinal isso podia ser a defesa ou o disfarce de uma personalidade a descobrir e (quem sabe?) a admirar. 
próprio historiador. As principais obras dedicadas à nossa revolução, parecem-me devedoras, directa ou indirectamente, desta tendência historiográfica, vulgarmente classificada como 'história dos vencedores'.

Na impossibilidade da análise pormenorizada de uma já vasta bibliografia, ${ }^{194}$ escolho duas obras que considero a vários títulos exemplares: a obra de Kenneth Maxwell The Making of Portuguese Democracy 195 e o já citado trabalho de Sánchez Cervelló A Revolução Portuguesa e a sua influência na transição espanbola. No primeiro caso estamos perante uma séria investigação dos acontecimentos daquela época, com particular cuidado na sua contextualização no xadrez mundial contemporâneo. Contudo, a opção de pensar por critérios políticos pré-definidos o fenómeno revolucionário, por um lado, e por outro a visível simpatia pelos vencedores, leva-o a uma leitura quase triunfalista da revolução acontecida, ou mais precisamente do seu resultado: a vitória da corrente moderada a quem reconhece um invulgar talento para anular com sucesso os extremos antagónicos. Valoriza-se, pois, a revolução como campo em que se confrontam determinadas dinâmicas decisivas para a formação do novo regime, mas os extremos, porque vencidos, são necessariamente desvalorizados ou, no limite, apenas considerados como obstáculos que mais ajudam a realçar a qualidade excepcional da vitória, tanto mais importante quanto constitui um significativo desvio ou quebra do padrão dominante das revoluções mundiais. "Não foram os "girondinos" que foram derrotados pelos "montanheses" como na revolução Francesa; ou, mais apropriado ao caso de Portugal, não foram os bolcheviques que derrotaram os mencheviques". Apesar dos prognósticos sombrios de Henry Kissinger, foi o "socialista moderado" Mário Soares que venceu.

${ }^{194}$ Das quais merecem especial destaque trabalhos historiográficos tão diversos como:António Reis, A Revolução de 25 de Abril de 1974, o MFA e o processo de Democratização, in António Reis (dir.) Portugal Contemporâneo, vol 6, Lisboa, Publicações Alfa, 1993; António José Telo, História Contemporânea de Portugal, vol.1, Lisboa, Editorial Presença, 2007; Maria Inácia Rezola, Os Militares na Revolução de Abril-O Conselho da Revolução e a Transição para a Democracia em Portugal (1974-1976), Lisboa, Campo da Comunicação, 2006; Maria Inácia Rezola, Mitos de uma Revolução, Lisboa, A Esfera dos Livros, 2007.

195 Kenneth Maxwell, The Making of Portuguese Denocracy, Cambridge, Cambrige University Press, 1995 
Em conclusão, segundo Maxwell "foi Kerensky quem sobreviveu, não Lenine". 196

No segundo caso, uma exaustiva e bem sucedida combinação de fontes históricas escritas e orais, um conhecimento íntimo dos acontecimentos, dos mais claros aos mais obscuros (caso da contra-revolução) bem como das suas complexas redes de causalidade, fazem de Sánchez Cervelló um reconhecido especialista da revolução de Abril. Mas, como assinala aliás o seu prefaciador, Hipólito de la Torre Gómez, a obra estrutura-se 'em torno do delineamento de um problema politico axial que é o desenvolvimento democratizador português'. ${ }^{197}$ Porventura residirá aqui o seu aspecto mais polémico, pois penso que Cervelló não evita os perigos de um certo determinismo, uma vez que desenha uma cadeia sequencial com os seus picos em datas como o 28 de Setembro, o 11 de Março e o 25 de Novembro, a qual vem consagrar um determinado modelo de democracia representativa ou parlamentar. Este modelo operatório leva o autor a introduzir na sequência quase vertiginosa dos acontecimentos uma racionalidade que eles de facto não tiveram, a qual, operando por divisões e exclusões, traçando uma fronteira entre zona escura e zona clara, faz excluir desta muitas e importantes manifestações. O que está em jogo é, pois, saber se é possível olhar este período como um continuum, uma sequência histórica, um processo teleologicamente conducente ao seu próprio fim, 25 de Novembro, ou se, pelo contrário, esse epílogo não foi uma fatalidade, mas antes uma possibilidade, vitoriosa sem dúvida, mas sempre uma possibilidade entre outras, que, vencidas embora, não deixaram de marcar profundamente o processo, os seus protagonistas, e afinal a própria fisionomia deste país.

Em conclusão: entre uma historiografia amnésica (que apaga o acontecimento) e uma historiografia selectiva (que dele apenas destaca os aspectos que contribuem de forma decisiva para um resultado muito próximo da história dos vencedores) tem oscilado a maior parte dos numerosos estudos sobre o 25 de Abril. Liga-os, afinal, a opção pelo modelo da continuidade, seja de longo curso, porque encontra as suas origens

${ }^{196}$ Ibidem p. 127

197 J. Sánchez Cervelló, op. cit. p. 8. 
distantes no próprio regime que a revolução derruba, ${ }^{198}$ seja de breve curso, porque, na variedade de forças por ela geradas, se privilegia uma delas e se desenha o seu percurso vencedor. Desse modelo, segundo uma lógica de continuidade, como atrás referi, resulta uma história-balanço, mais voltada para o resultado de um processo de transformação, do que para a natureza específica e as dinâmicas próprias desse mesmo processo.

Qualquer das duas correntes assenta em pressupostos ideológicos e metodológicos que fatalmente conduzem de forma clara ou velada à subalternização do acontecimento revolucionário, encarado como uma espécie de interregno ou suspensão do tempo. No primeiro caso apagado, no segundo selectivamente valorizado. Um e outro, contornando a dificuldade em penetrar nessa espécie de vazio conceptual e histórico, optando por leituras retrospectivas e/ou prospectivas que inscrevem e legitimam no passado o sentido das evoluções posteriores.

Assim, visto do exterior, esse interregno não deixa de assumir um relativo grau de opacidade. Não nas suas origens (causas) e nos seus epílogos (efeitos), que, portanto, lhe são anteriores e posteriores, mas justamente no seu interior, nesse imenso cenário que fica após todos os esforços de conceptualização que o historiador que avança por conceitos explícitos (e implícita ideologia) desvaloriza e trata como parte residual. Por outras palavras: no seu esforço de distanciação, na sua recusa em assumir as emoções, as paixões e até as ilusões da revolução sobre si mesma, o historiador corre o risco de deixar de fora o próprio acontecimento. Como escreve Gonçalo M. Tavares, 'Em relação a qualquer período revolucionário, o Tempo, revelando-se como o tal escultor justo, tem tendência a apagar, a tirar da

\footnotetext{
${ }^{198}$ Este recuo pode ainda ser maior, como acontece com autores que, reforçando a ideia de continuidade, situam a origem do regime democrático, não no consulado marcelista, mas ainda mais atrás no próprio salazarismo. Por exemplo, Manuel de Lucena analisa a sociedade actual e as suas transformações, à luz da persistência do sistema corporativista que caracterizou o Estado Novo. E estende o modelo continuista à própria estrutura política, considerando que existem significativas semelhanças entre a constituição plebiscitada em 1933 e a aprovada pela Assembleia Constituinte, as 'irmãs inimigas', como lhes chama. E Joaquim de Aguiar chega a apelidar a sociedade actual de 'pós-salazarista', porque 'na aparente diferença radical que teria sido introduzido pela democracia está (...) uma das razões mais fortes para a linha de continuidade que constitui o pós-salazarismo, exactamente porque encobre, sob um disfarce formal, essa continuidade real'.
} 
escultura final - como se fosse lixo - a excitação (positiva, negativa) e a ficar, como um bom arquivista, apenas com os factos - na suposição de que estes existem, assim, puros - enfim, a ficar apenas com aquilo a que poderíamos chamar forma final. Como se alguém dissesse: este é o material de que é composta a forma, e a matéria que está no chão é o que estava a mais. Digamos que a História funciona como uma testemunha não envolvida emocionalmente - alguém que vê o que acontece, mas não o sente'199. Encarando a revolução como uma invulgar concentração de acontecimentos violentos geradores da máxima quantidade e intensidade de emoções no mais curto período de tempo, tentar despi-la dessa vibração emocional (o que se sente) reduzindo-a ao que se vê, é como separar a matéria da forma, ou ainda, nas palavras do autor, a 'excitação' e os 'factos. ${ }^{200}$ No limite o estudo dos factos, nas suas causas e consequências, exige distância (a famosa distanciação histórica), enquanto a excitação (positiva, negativa), só possível pela proximidade, é, muitas vezes, o essencial. Regressando à pergunta inicial - como pensar a revolução? - será então que teremos de concluir com P. Ricoeur que "l'analyse casse proprement le récit historique" porque "traite un problème, non une période"?201 Isto é, porque pretende explicar esse problema segundo grelhas conhecidas e de alguma forma testadas que, inevitavelmente, se mostrarão incapazes para compreender o momento revolucionário como acontecimento fundador, momento de ruptura com o conhecido e origem de algo radicalmente novo e diferente.

199 Gonçalo M. Tavares, Prefácio a Os Dias Loucos do PREC-Do 11 de Março ao 25 de Novembro de 1975. de Adelino Gomes e José Pedro Castanheira. Lisboa, Expresso/Público, 2006.

200 Nesse interessante trabalho, o autor ensaia um inovador olhar sobre a revolução, que é também uma denúncia das incapacidades e deficiências dos historiadores, por um lado no conhecimento integral desse mesmo acontecimento, e por outro, na sua transmissão às novas gerações. Assim, se o par de opostos excitação/factos enquadra a primeira questão, a segunda é por sua vez analisada através do par intensidade/aprendizagem. Partindo da ideia de que a aprendizagem é um processo ao mesmo tempo intelectual e emocional, o autor, que tinha quatro anos em 1975, considera que a sua geração e seguintes só poderão perceber o que se passou se lhes possibilitarem a entrada no interior do próprio acontecimento, e não ficarem apenas pelo lado frio e distante de um amontoado de nomes e datas, porque 'existe uma intensidade emocional mínima, abaixo da qual ouves e esqueces, acima da qual, porque sentes, ouves e recordarás'.

201 Paul Ricoeur, op. cit. p. 310 
$\mathrm{Na}$ verdade, neste jogo de espelhos entre a revolução como processo histórico objectivo e a revolução como conjunto de acontecimentos (acontecidos e vividos) se insinua a persistente obscuridade que ameaça qualquer uma das perspectivas aqui analisadas. Desse jogo arriscado se dá conta J. Medeiros Ferreira, ao afirmar que embora não tenha 'a pretensão de se identificar com Michelet para a Revolução Francesa ou Trotsky para a Revolução Russa' não deixa, por outro lado, de reconhecer que 'a percepção dos contemporâneos sobre os acontecimentos que viveram é um dado comportamental que o historiador deve ter na devida conta.'202

O autor parece, assim, apontar para mais longe, na busca de um modelo que permita a aproximação possível ao fenómeno revolucionário ${ }^{203}$, de que a referência a Fernão Lopes é um dado esclarecedor. Verdadeiro cronista de ambientes e de emoções colectivas, o fundador da historiografia nacional permanece como modelo intemporal de uma história que valorize uma estratégia narrativa como única forma de atingir uma compreensão mais profunda e autêntica dos acontecimentos e sua natureza irredutível a meras estruturas explicativas, pretensamente neutras ou objectivas. 'Custou ainda ao autor não ter recriado, pela narração, o clima emocional de certos momentos, nomeadamente o desencadeado pelas grandes manifestações que ocuparam praças e ruas de Portugal entre 1974 e 1975. E, no entanto, Fernão Lopes esteve sempre presente como um paradigma literário soterrado pela moderna forma de escrever história como se esta fosse objecto de relatório administrativo' ${ }^{204}$. E é justamente a essa componente existen-

\footnotetext{
${ }^{202}$ J. Medeiros Ferreira, op. cit. p.11/12

${ }^{203}$ Recorde-se que se trata de um dos poucos autores que não hesitam em utilizar o vocábulo 'revolução' num dos primeiros trabalhos publicados em Portugal a ela dedicados. Trata-se da obra sintomaticamente intitulada Ensaio Histórico sobre a Revolução do 25 de Abril, Lisboa, Imprensa Nacional Casa da Moeda, 1983. Revolução, pois, e não 'Transição para a democracia', ou 'Processo de Democratização'. Mesmo se, posteriormente, no Prefácio ao seu Portugal em Transe (outro título igualmente revelador) ele invoca o recurso que fez à expressão 'revolução imperfeita' (e qual a não é?) já em 1985: 'Julgo assim ficar ao abrigo de qualquer mudança, que se venha a verificar, na natureza da revolução, implicando novas interpretações. Não será pertinente recordar que a revolução liberal de 1820 só pode ser bem entendida pelos eventos da guerra civil subsequente e pela vitória de 1834? O título revolução imperfeita destinava-se a cobrir a falta de perspectiva temporal mas também indicava um movimento incompleto' .
}

${ }^{204}$ Medeiros Ferreira, op. cit, p.12 
cial, que subverte modos de sentir de viver e de pensar, que se sobrepõe a todas as outras dimensões do viver individual e colectivo, que lança mão José Medeiros Ferreira para caracterizar a revolução de 1974. 'O 25 de Abril desencadeou profundas alterações nos valores e na vida social nacional. Ele marca uma era, tantas são as ocasiões em que é tomado como referência: Antes do 25 de Abril... só com o 25 de Abril... depois do 25 de Abril... são expressões coloquiais quotidianas que se impuseram nos últimos vinte anos. A data de 25 de Abril de 1974 marca, pois, o século xx e divide a sociedade em antes e depois. Será isso uma revolução? É certamente uma era'205.

O desejo de Medeiros Ferreira aqui fica, pois, como desafio a uma nova historiografia da revolução. Do que se trata, em nosso entender, é de procurar o sentido daquela experiência concreta, no seu próprio interior, na sua lógica interna, e não em qualquer visão teleológica da história. De contrapor a uma história dos fins, sejam eles o progresso histórico, a razão divina ou a síntese socialista final, todos eles pairando de fora e acima, uma história dos meios e dos agentes na sua própria natureza e autonomia. Isto é, de uma história que não escolha os seus objectos como instrumentos de uma narrativa ou meta-narrativa descontaminada, mas sim como processos com sentido próprio, antes de mais para os sujeitos que viveram determinadas experiências, que cabe à história dignificar cientificamente, e à politica recuperar como possibilidade de inspiração de lutas futuras.

205 Ibidem, p.11 